Криворізький педагогічний інститут ДВНЗ «Криворізький начіональний університет»

\title{
УДОСКОНАЛЕННЯ ПРОВЕДЕННЯ УРОКІВ АНГЛІЙСЬКОї МОВИ
}

У статті на основі аналізу типових помилок учителів при проведенні уроків англійської мови даються рекомендачії з підвищення ефективності проведення уроків.

Ключові слова: критерії оцінювання, компетентність, иілі уроку, аналіз помилок.

В статье на основе анализа типичных ошибок учителей при проведении уроков английского языка даются рекомендащии по повышению эффективности проведения уроков.

Ключевые слова: критерии оценивания, компетентность, цели урока, анализ ошибок.

On the base of analysis of teachers' common mistakes during English lessons recommendations to improve the effectiveness of lessons are given in the article.

Key words: evaluation criteria, competence, goals of the lesson, error analysis.

Існують положення про проведення конкурсів, $є$ відгуки учителів про результати участі в конкурсі «Учитель року (номінація: Англійська мова)», є рекомендації щодо вдосконалення самої процедури проведення конкурсу, але немає детального аналізу уроків конкурсантів з рекомендаціями щодо підвищення ефективності проведення уроків.

Mema cmammi - проаналізувати уроки англійської мови, проведені учителями під час конкурсу «Учитель року -2012 (номінація: англійська мова)» у Дніпропетровській області, надати рекомендації з удосконалення професійної компетентності учителів.

Конкурс створює широке поле для професійного спілкування, особистісного зростання педагогів, забезпечує обмін передовим педагогічним досвідом. Учитель, який претендує на титул переможця, має бути не лише відмінним предметником та володіти сучасними методиками і вміннями передавати свій досвід, але й бути яскравою особистістю, яка вміє 
переконувати і вести за собою. Головні цілі конкурсу - пропаганда пріоритетів освіти, формування суспільного уявлення про творчо працюючих педагогів, підвищення престижу педагогічної професії, пошук не лише кращого із найкращих, але й надання прикладу тим, хто знаходиться в активному пошуку нових можливостей або робить лише перші кроки до своєї майстерності.

Конкурс «Учитель року - 2012 (номінація: англійська мова)» в Дніпропетровській області проводився в декілька етапів при виконанні багатьох завдань 3 перевірки теоретичної підготовки і практичних умінь конкурсантів.

1 етап - це проведення конкурсів на рівні районів та міст, за результатами яких було відібрано 30 кращих учителів 3 різних куточків Дніпропетровської області. Конкурсанти представляли м. Дніпропетровськ, м. Дніпродзержинськ, м. Кривий Ріг, м. Верхньодніпровськ, м. Марганець, м. Нікополь, м. Вільногірськ, м. Жовті Води, м. Новомосковськ, м. Синельникове, селища Магдалинівка, Царичанка, Маломихайлівка, Петріківка, Кринички, Павлівка, Іванівка, Широке та Апостолове.

Участь у конкурсі - це не просто збір напрацьованого матеріалу. Підготовка матеріалів для кожного конкурсанта $\epsilon$ справжньою школою підвищення кваліфікації, оскільки вчитель у цей період найбільш інтенсивно спрямовує свої зусилля на осмислення та структурування власного досвіду. Освоєння технології самоаналізу педагогічного досвіду, виділення найцінніших компонентів, формування вміння оцінити власні педагогічні знахідки з точки зору їх науковості, доцільності, технологічності - все це створює передумови для успішного професійного росту. Шлях педагога до перемоги в конкурсі $\epsilon$ надзвичайно кропіткою глибинною роботою 3 перебудови самого себе. Ні стать, ні вік, ні місце народження переваг у перемозі не надають.

Незважаючи на творчу природу конкурсу, він має чіткі критерії оцінювання. До наступного туру допускаються учасники, які успішно виконали завдання попереднього етапу. Конкурсанти відбіркового туру надали звіти з власного педагогічного досвіду у вигляді портфоліо, які були оформленні згідно із встановленими вимогами, виконали тестові завдання 3 теорії (методики викладання іноземних мов, психології та англійської мови). Портфоліо переконували своїм об'ємом матеріалу, учителям було чим поділитися 3 точки зору влас- 
ного досвіду викладання англійської мови; кожний конкурсант намагався представити якомога більше (розглядалися роботи об'ємом до 500 сторінок). Це були теоретична та практична частини з розробками уроків та рекомендаціями.

Без сумніву, кожен учитель має напрацьовані роками матеріали 3 предмету, оскільки саме вчителя можна легко впізнати за великою кількістю тек, розробок, підручників та зошитів на столі, сумці формату A-4, 3 якою він ходить на роботу. Але, на жаль, кількість матеріалу - не шлях до перемоги. Не всім конкурсантам вдалося оформити матеріал за критеріями: викласти його доступно, коротко i, одночасно, повністю від актуальності та мети до результату, розкрити авторську концептуальну позицію та шляхи їі реалізації.

Основні помилки, як ми вважаємо, є недоліками при підготовці учителя у ВНЗ та на курсах підвищення кваліфікації становлять: професійні вміння визначити актуальність роботи, об'єкт, предмет дослідження, оформлення літератури - ті вміння, які мають розвиватися при написанні декількох курсових робіт і випускної роботи при закінченні ВНЗ.

За критеріями оцінювання оформлення портфоліо було відібрано 10 кращих робіт, закономірно, що ті ж самі конкурсанти мали досить високі бали за виконання інших завдань (3 методики викладання іноземних мов, психології, перевірки рівня володіння англійською мовою).

Отже, у відбірковому турі взяли участь 30 учителів і лише 10 були рекомендовані для участі в наступному турі, де мали демонструвати свої практичні вміння та вести боротьбу за 1 місце переможця, що має представляти Дніпропетровську область у республіканському конкурсі, та за 2 і 3 місця лауреатів.

Проведення цього туру відбувалося у м. Нікополь на базі гімназії № 15 протягом 3 днів. Були проведені конкурси домашнього завдання, майстер-класу, проведення фрагментів уроку англійської мови, написання розгорнутого конспекту уроку та самоаналізу. У результаті цієї нелегкої боротьби визначилися 3 лідери, які в змаганні за 1 місце проводили відкриті уроки в новому для них класі.

Мета: демонстрація учителем своєї професійної компетентності та практичного досвіду.

Регламент: 40 хвилин. 
Учитель залежно від місця уроку в темі (розділі), типу уроку визначав сам його структуру, використовував той чи інший набір методів викладання.

Як відомо, урок є головною складовою частиною навчального процесу. Навчальна діяльність учителя і учнів в значній мірі зосереджується саме на уроці. Ось чому якість підготовки учнів 3 тієї чи іншої навчальної дисципліни в багатьох випадках визначається рівнем проведення уроку, його змістовними та методичними компонентами. Для того, щоб цей рівень був достатньо високим, треба щоб учитель під час підготовки уроку намагався зробити його своєрідним педагогічним твором зі своїм задумом, зав'язкою, кульмінацією та розв'язкою як у будь-якому витворі мистецтва. Учити на уроці та навчити - це показник високого рівня професійної компетентності учителя. Будь-яку модель уроку іноземної мови можна оцінити згідно визначених параметрів, кількість яких за даними наукових досліджень може дорівнювати тридцяти [1].

Узагальнена схема аналізу уроку іноземної мови містить наступні об'єкти: ступінь результативності уроку; форми роботи на уроці; способи введення нового матеріалу; типи використаних вправ; контроль та оцінювання на уроці; характеристика взаємодії вчителя та учнів; раціональність використання часу на уроці; мова учителя; врахування дидактикометодичних принципів навчання іноземної мови [2].

3-поміж загальних позитивних моментів уроків, які були проведені лідерами конкурсу, можна зазначити такі: було підготовлено матеріал для повторення; всі конкурсанти тримали темп проведення уроку; під час виконання завдання учителя ходили по класу, надаючи допомогу учням у виконанні вправ; демонстрували вміння організувати взаємодію учасників заняття між собою, створювали та підтримували високий рівень мотивації і високу інтенсивність діяльності учнів на уроці; використовували різноманітні прийоми, включаючи ігрові моменти; раціонально використовували час на уроці; забезпечували логічний перехід від однієї діяльності до іншої; розподіляли учнів на групи за вибором завдання, пов'язаного тематично (за типом музики, фрагментом малюнка, тощо); використовували різноманітну наочність (малюнки, предмети, схеми, презентації в Power Point, демонстрували дії тощо). 
Однак хвилювання конкурсантів також мало вплив на хід конкурсу. Одразу було видно, як не треба робити , що можна і потрібно поліпшувати, тому були виявлено такі проблеми:

1. Неповнота планування мети уроку.

Урок іноземної мови, мабуть, як ніякий інший, має величезний освітній потенціал. Навчальний у тому числі, не лише освітній. Навчання органічно містить у собі і пізнання, і розвиток, і виховання. Іноземна мова перестала бути самоціллю, а розглядається як спосіб пізнання навколишнього середовища та спосіб саморозвитку. Таке розуміння цілей вивчення іноземної мови знайшло своє відображення і в цілях навчання англійської мови у школі, які реалізуються через формування комунікативної компетентності, що в свою чергу включає мовний та мовленнєвий аспекти.

В основі навчальних посібників з іноземної мови покладено концепцію комунікативного іншомовного навчання «Розвиток індивідуальності в діалозі культур». У межах конкретного уроку мають бути вираженими чотири глобальних аспекти іншомовного навчання - освітній (соціокультурний), розвивальний, виховний і навчальний.

Урок іноземної мови завжди починається із повідомлення про значущий цікавий факт іншомовної культури, який усвідомлюється учнями в процесі читання, аудіювання, говоріння та письма. Тому першою метою уроку є освітня мета, тобто, оволодіння знаннями про навколишній світ, свою та інші країни (соціокультурними знаннями), включаючи знання про мову як частину іноземної культури. Для цього використовуються різноманітні засоби: фото, фрагменти фільмів, мапи, етикетки, уривки 3 автентичної літератури, репродукції художників, фонові знання, що містяться в крилатих виразах, прислів'ях та інший країнознавчий матеріал, який відображає реальність.

Другим аспектом іншомовного навчання $є$ розвивальний аспект. Отже, розвивальною має бути і друга ціль уроку. Об'єктами розвитку виступає здатність до осмисленого сприйняття, збільшення об'єму уваги, мимовільне запам'ятовування, антиципація структур, здогадка та аналіз, абстрагування та узагальнення, логічний виклад, планування висловів, вираження різноманітних почуттів, оцінка й самооцінка, комунікабельність, імітація, комбінування, імпровізація тощо. 
Важливим аспектом уроку є виховна мета. Змістом виховного аспекту іншомовного навчання $\epsilon$ духовно-моральний розвиток учнів. До цього змісту входять патріотизм, соціальна солідарність, громадянська позиція, сімейні цінності, праця та творчість як цінність, мистецтво та література, природа як цінність тощо.

Нарешті, четвертий аспект вивчення іноземної мови - навчальний. Це практична мета - оволодіння складним умінням спілкуватися в між культурному діалозі, який грунтується на вмінні говорити, аудіювати, читати та писати. У зв'язку з цим практичною метою уроку завжди $є$ оволодіння мовними навичками, які лежать в основі мовленнєвих вмінь або вдосконалення цих навичок чи розвиток конкретних вмінь або оволодіння вмінням власне спілкування [3].

Безумовно, об'єкти всіх аспектів різноманітні та численні, але вони всі мають бути чітко визначені та сплановані окремо для кожного уроку. На жаль, не всі учасники конкурсу правильно визначили об'єкти соціокультурної та розвивальної цілей.

2. Багато часу на уроці займало мовлення вчителя.

Щоб організувати діяльність учнів на уроці, співвідношення 10: 90 на користь учнів вважається оптимальним [5], а ідеальним є співвідношення, при якому мовлення учителя займає лише 2 \% часу і сам учитель відходить на «задній план».

3. Мали місце помилки, пов'язані 3 технологією спілкування.

Не завжди мовлення учителя було достатньо емоційним, мало використовувалися жести, міміка та виразність мовлення. Використовувалися одноманітні фрази для похвали, не було фраз, стимулюючих активність учнів.

Учителю необхідно демонструвати різні моделі позитивної поведінки, в тому числі за допомогою моделювання різноманітних комунікативних ситуацій. Учням слід надавати можливість відкрито говорити про свої почуття та емоційний стан. Спілкування неможливе без емоційності та виразності. Учитель повинен живо й адекватно реагувати на відповіді учнів: «Невже?», «Це цікаво!», «Молодець!» та інші. Одним із можливих засобів створення сприятливого мікроклімату є похвала учня. Вона може бути вербальною: «Well done!», «How clever you are!», «Good boy/girl!», «That's excellent work!»,«That's a good start!», «You're really trying hard!» та 
інші. Невербальні методи заохочення: посмішка, жести, міміка, аплодисменти тощо. Похвалу учителя також можна виразити в роздавальних картках, жетонах. Оцінювання може бути і у вигляді сонечка, де промені видаються як бонус за успішну відповідь. Перемагає той, чиє сонечко яскравіше [4].

4. Неправильна технологія виправлення помилок, прийомів контролю.

Не було роботи над помилками, проводилося в основному пряме виправлення помилок, що не завжди є ефективним. Не проводилася фіксація типових помилок учнів. Не завжди мав місце аналіз помилок. Контроль був лише з боку вчителя, не мали місце взаємо- та самоконтроль.

Усі ми навчаємося на помилках. Як це не дивно, але можна 3 впевненістю сказати, що вони $є$ двигуном подальшого процесу навчання. Уважається, що виправлення помилок $\epsilon$ також важливою частиною процесу навчання, оскільки є органічною складовою процесу оволодіння як іноземною, так і рідною мовою. У методиці загальновідомим є положення про те, що рішення «виправляти чи не виправляти» приймається залежно від виду та мети роботи. У випадку, коли учні при виконані завдання говорять 5-7 речень, виправлення всіх помилок $є$ недоцільним, оскільки це може «збити» того, хто говорить. Тим паче це недоцільно, якщо учні не роблять помилок, які не перекручують думку, або заважають взаєморозумінню.

Коректне виправлення помилок і зворотній зв'язок - основна складова професійної компетентності учителя іноземної мови. Постійне виправлення помилок визиває в учнів страх i знижує мотивацію, в той час як лояльність по відношенню до помилок може визвати підвищену самооцінку і знехтування чистотою мовлення. Учні очікують від учителя виправлення помилок і сам момент виправлення помилок необхідно провести та ввести в структуру уроку як спеціальний етап роботи над помилками. При цьому не слід забувати, що чим частіше контролюється робота всіх учнів, тим легше виявити типові помилки та ускладнення, а також показати учням щирий інтерес учителя до їхньої роботи. Учитель має розв’язати сам: виправляти помилки чи ні, коли, що та як виправляти.

Існує багато прийомів виправлення помилок залежно від виду мовленнєвої діяльності та рівня підготовки учня. Поперше, доцільно проводити фіксацію найбільш часто повто- 
рюємих помилок, які можна систематизувати за категоріями (лексичні, граматичні, орфографічні та інші). По-друге, треба спрямовувати самостійну роботу учнів на запобігання типових помилок і розвиток вміння самим знаходити власні помилки при виконанні вправ. Це можна зробити і у формі гри та проводити у класі. Наприклад, заздалегідь готуються картки 3 типовими помилками та картки 3 правильним варіантом. Кожний учень отримує по три картки тієї та іншої категорії. Завдання учнів - зрозуміти, на якій із карток $є$ помилка, обійти групу і знайти картку з правильним реченням. Можна використовувати також інші ігри, наприклад, аукціон 3 покупки правильних речень. Окрім того, ефективним $є$ заповнення спеціальних таблиць, які містять графи: Mis-pronunciation, New vocabulary, You said..., You should have said...[6].

Існує досить широкий вибір таких методів, необхідно їх використовувати, але на уроках це, на жаль, не спостерігалося.

5. Помилки з утримування та розвитку уваги учнів.

Не всі учні були залучені до роботи, часто лише ті, хто був активним на уроці. При висловлюванні одного з учнів не залучалася увага інших, таким чином, учень відповідав лише учителю, не використовувалися різноманітні прийоми на переключення уваги учнів на виконання нового завдання. При прослуховуванні аудіозапису учителем ігнорувалися настанови на розуміння змісту.

Сучасні уроки англійської мови характеризуються великою активністю і потребують від учнів концентрації уваги.

Швидка втомлюваність спричиняється специфікою предмета: необхідністю великої кількості тренувальних вправ. Успішність сприйняття, як і інших пізнавальних процесів, базується на організації уваги, в багатьох випадках залежить від уміння концентрувати увагу, що надає можливість реалізувати скриті резерви головного мозку. В наш час на основі методу концентрації уваги було розроблено, запатентовано та впроваджено програми навчання іноземних мов ( наприклад, 25-й кадр), де головним фактором є саме концентрація уваги. Як відомо, в ході уроку мають місце кризи уваги. Вони слідують один за іншим: 1 - на 14-18 хвилині; 2 - через 11-14 хвилин; 3 - через 9-11 хвилин; 4 - через 8-9 хвилин і далі інтервали між кризами уваги слідують кожні 4-5 хвилин (за Висоцькою С. І.). Учні з 1-ої по 4-ту хвилини здатні засвоїти максимально близько 60\% наданої інформації, з 5-ої по 23-ю 
хвилину - близько 80\%, з 24-ої по 34-ту - близько 45-50\%, 3 35-ої хвилини до 45-ої йде спад (тобто зниження можливостей сприйняття і засвоєння отриманої інформації) до 6\% [7]. Ці дані доцільно враховувати і за необхідності змінити структуру уроку.

Учитель на уроці зазвичай закликає учнів бути уважними, але одноманітність закликів призводить до зниження ефективності. Поміж деяких прийомів управління увагою учнів на уроці є: попередній запис плану уроку на дошці; підвищення або зниження голосу; стукання по столу; несподіваність, кольоровість, динамізм у поданні інформації; яскравість, образність і життєвість конкретних прикладів; ефект «яскравої плями», повідомлення класу інтригуючого матеріалу, який має захопити увагу учнів, але при цьому обов'язково пов'язаного $з$ темою уроку. У якості «яскравої плями» можуть бути використані казки і легенди, фрагменти із художньої літератури, події з історії, культури та повсякденного життя, жарти тощо; попередження учнів про складність завдання; підкреслення значущості інформації фразами типу «це важливо знати», «це буде в контрольній роботі» інше; використання графічних схем; для мобілізації уваги під час усного опитування учнів доцільно поставити запитання всьому класу і лише після паузи назвати ім'я того, хто має відповісти на запитання. В результаті відповідати готується весь клас, а питає вчитель лише когось одного. Треба обов'язково залучати всіх учнів, щоб кожен з них міг доповнити відповідь (або виправити можливі помилки у відповіді). Тоді весь клас буде зосереджений на роботі; оптимальний темп уроку; робота 3 картками; прийом «закритої дошки»; включення до роботи максимальної кількості учнів; створення ситуацій змагального характеру; заохочення окремих учнів за увагу на уроці; незначне покарання за відсутність уваги [7].

6. Використання наочності не завжди було виразним.

Треба пам'ятати, що неправильно підібраний або складений наочний засіб може погіршити сприйняття і розуміння учнями сутті матеріалу, що подається учителем на уроці. При складанні наочності і її поданні треба враховувати такі психологічні закономірності: першорядний матеріал має бути розташований у центрі; фігури, подібні за будь-яким елементом (кольором, розміром, формою, тощо) при сприйманні об'єднуються і групуються; близько розташовані фігури 
сприймаються краще; із контрастних кольорів найбільш питому вагу має поєднання чорного і білого, чорного і жовтого; краще сприймаються умовні знаки, контур яких утворений прямими лініями, тобто надписи друкованими літерами сприймаються легше, ніж прописними; сприйняття матеріалу покращується, якщо окремі стенди, плакати, малюнки розділені порожнім простором; кількість основних зображень на плакаті, схемі, слайді має бути в межах п’яти-семи, що відповідає нормальному об'єму сприйняття; кількість подань наочності (слайдів, схем, тощо) не має перевищувати чотирьох-десяти протягом одного уроку, а тривалість подання; не більше 15-45 секунд; оптимальна тривалість демонстрації навчального фільму на уроці - не більше 10 хвилин, а максимальний час використання ТЗН на уроці - 20-25 хвилин; динамічна наочність більш корисна, ніж статистична; довготривалий показ статистичної наочності знижує іншомовну активність учнів, оскільки дозволяе їм у цей проміжок часу користуватися рідною мовою [8].

7. Недоліки, пов'язані з інструкціями до завдань.

Інструкції були не завжди чіткими, тому досить часто виникали зайві питання з уточнення завдання. Формулювання ситуацій не передбачало алгоритму висловлювання. Після подачі завдання не фіксувався час на виконання цього завдання. Був відсутнім змагальний момент.

Комунікативна ситуація, як метод навчання говорінню, складається 3 чотирьох факторів, які певним чином впливають на мовлення. При формулюванні ситуації вказуються обставини, розподіляються ролі, обговорюються умови, прогнозується кінцевий продукт. Обов'язково подається алгоритм висловлювання. Не існує ситуації «Моє улюблене місто», оскільки це є темою уроку, яка включає безліч ситуацій, які мають бути сформульовані згідно з конкретними параметрами.

Учнів треба вчити працювати в обмеженому часовому режимі, це розвиток саморегуляції особливості.

Невміння розрахувати час на виконання завдання вважається однією 3 основних проблем учнів при виконанні тестових завдань при написанні зовнішнього незалежного оцінювання (ЗНО) з англійської мови.

8. Не змінювалися мовленнєві партнери при роботі в паpax. 
Не завжди перевірялось виконання завдання в режимі «учень - клас». Не змінювалося місце відповіді учнів, майже завжди всі учні відповідали лише 3 місця.

Треба пам'ятати, що зміна місця, мовленнєвих партнерів, їх характеру, ролей, нова мовленнєва задача, новий співрозмовник, нові форми спілкування - все це $є$ дуже ефективними способами створення новизни і реалізація принципу новизни як одного із принципів навчання іноземній мові.

9. Не дотримувалися взаємозв'язку роботи в класі з домашнім завданням.

Виконання домашнього завдання не було підготовлено в ході уроку. Домашнє завдання не завжди записувалося на дошці, був відсутній інструктаж 3 виконання домашнього завдання.

Домашня робота є природнім і логічним продовженням роботи в класі. Можна встановити такі цілі, до яких треба прагнути при організації домашньої роботи: закріплення в пам'яті матеріалу, над яким працювали в класі; в окремих випадках - більш поглиблене і розширене його вивчення; повторення раніше вивченого матеріалу; удосконалення різноманітних навичок і вмінь, необхідних для самостійної роботи шляхом виконання відповідних завдань.

Домашнє завдання доцільно записувати на дошці, надаючи необхідні рекомендації з його виконання. Саме подання домашнього завдання може мати місце на будь-якому етапі уроку залежно від навчальної ситуації. Ця процедура, як правило, займає дуже маленький проміжок часу, але має велике значення.

10. Аналіз роботи учнів на уроці був відсутнім.

При оцінюванні роботи учнів на уроці учителі не надавали коментарі з приводу їх успіхів або участі в роботі на уроці, оцінки не аргументувалися.

Рефлексію учителя часто плутають 3 оцінюванням. Часто учителі зовсім не оцінювали роботи учнів на уроці. Оцінювання та коментування роботи учнів на уроці має бути обов'язковим елементом його завершального етапу.

Всі зазначені рекомендації з удосконалення уроків англійської мови - це умови розвитку вище професійної компетентності учителя.

Професійна компетентність - це динамічний процес засвоєння і модернізації професійного досвіду. Аналіз уроків спеціалістами, самоаналіз активізує професійний розвиток 
педагога, сприяє розвитку індивідуальних професійних якостей, накопиченню професійного досвіду, що передбачає непереривний розвиток і самовдосконалення.

\section{Література}

1. Бухбиндер В. А. Основные типы уроков иностранного языка и их дидактико-методические модели / В. А. Бухбиндер // Общая методика обучения иностранным языкам : [хрестоматия] / сост. Леонтьев А. А. - М. : Русский язык, 1991. С. 137-139. 2. Гаврилова Т. А. Психологический анализ урока : [метод. пособие] [Электронный ресурс] / Т. А. Гаврилова. - Уссурийск, 2000. Режим доступа: http://pdb.uspi.ru/book_1544/ 3. Игна О. Н. Анализ урока в оценке учителя иностранного языка [Электронный ресурс] / О. Н. Игна. - Режим доступа:http://pedsovet.org/component/ option,com mtree/task,viewlink/link id,5940/Itemid,118/

4. Кузовлев В. П. Четыре аспекта образовательного потенциала урока [Электронный ресурс] / В. П. Кузовлев. - Режим доступа: http://iyazyki.ru/2011/12/potentsial-uroka/ 5. Пантилеева М. C. O некоторых способах развития эмоционального интеллекта младших школьников на уроках английского языка [Электронный ресурс] / М. С. Пантилеева. - Режим доступа: http://eng.1september.ru/ article.php?ID=200701804 6. Шипилова С. P. Современный личностно-ориентированный урок [Электронный ресурс] / C. Р. Шипилова. - Режим доступа: http://nsportal.ru/nachalnayashkola/blog/sovremennyi-lichnostno-orientirovannyi-urok. ДВНЗ «Криворізький національний університет»

\section{ЕМОЦЙНИЙ АСПЕКТ У ФОРМУВАННІ КОМУНІКАТИВНОЇ КОМПЕТЕНЦІЇ УЧНІВ ПІД ЧАС НАВЧАННЯ МОРФОЛОГІЇ}

У статті розкрито емочійний аспект у формуванні комунікативної компетениії учнів, запропоновано приклади завдань, які можуть бути використані в процесі навчання морфологї.

Ключові слова: емоції, види емочій, комунікативна компетенція, навчання морфологї.

В статье раскрыт эмоциональный аспект в формировании коммуникативной компетенции учащихся, предложены примеры заданий, которые могут быть использованы в прочессе изучения морфологии.

Ключевые слова: эмоции, виды эмочий, коммуникативная компетенция, обучение морфологии. 